CLINICAL ETHICS

\title{
Project Examining Effectiveness in Clinical Ethics (PEECE): phase 1-descriptive analysis of nine clinical ethics services
}

\author{
M D Godkin, K Faith, R E G Upshur, S K MacRae, C S Tracy the PEECE Group, on behalf of \\ Investigators
}

J Med Ethics 2005;31:505-512. doi: 10.1136/jme.2004.010595

See end of article for authors' affiliations

\section{Correspondence to:} M D Godkin, 30 The Queensway, Toronto, Ontario M6R 1B5, Canada; godkind@smh. toronto.on.ca

Received

15 September 2004

In revised form

19 November 2004

Accepted for publication

25 November 2004

\begin{abstract}
Objective: The field of clinical ethics is relatively new and expanding. Best practices in clinical ethics against which one can benchmark performance have not been clearly articulated. The first step in developing benchmarks of clinical ethics services is to identify and understand current practices.

Design and setting: Using a retrospective case study approach, the structure, activities, and resources of nine clinical ethics services in a large metropolitan centre are described, compared, and contrasted.

Results: The data yielded a unique and detailed account of the nature and scope of clinical ethics services across a spectrum of facilities. General themes emerged in four areas-variability, visibility, accountability, and complexity. There was a high degree of variability in the structures, activities, and resources across the clinical ethics services. Increasing visibility was identified as a significant challenge within organisations and externally. Although each service had a formal system for maintaining accountability and measuring performance, differences in the type, frequency, and content of reporting impacted service delivery. One of the most salient findings was the complexity inherent in the provision of clinical ethics services, which requires of clinical ethicists a broad and varied skill set and knowledge base. Benchmarks including the average number of consults/ethicist per year and the hospital beds/ethicist ratio are presented.

Conclusion: The findings will be of interest to clinical ethicists locally, nationally, and internationally as they provide a preliminary framework from which further benchmarking measures and best practices in clinical ethics can be identified, developed, and evaluated.
\end{abstract}

They suggest that these goals are accomplished through consultation, conflict resolution, and educational processes.
Again, however, there is little known about how these approaches are realised in practice and whether or not they are effective in achieving the goals for clinical ethics set forth by Fletcher and Siegler.

The structure, activities, resources, and effectiveness of clinical ethics committees that provide consultation services have been previously described in some detail. ${ }^{3-10}$ However, there is limited empirically based information in the literature concerning the structure, activities, resources, and effectiveness of clinical ethics services or programmes that utilise a "lone" ethics consultant model of service delivery. ${ }^{6}{ }^{10}{ }^{11}$ This particular model dominates the clinical ethics landscape in several Canadian geographical areas, including the locations of this study. In a lone ethics consultant model, accountability and responsibility for the delivery of clinical ethics service generally falls upon a single individual(s) who has been hired by the facility as a clinical ethicist. A clinical ethicist rather than a team of ethics committee members carries out consultations. Knowledge about the structure, activities, resources, and effectiveness of the lone ethics consultant model of service delivery could contribute to the development of evidence based best practices and benchmarking measures for clinical ethics services. In future studies, it may be possible to compare this lone ethics consultant model of care delivery to an ethics committee model. Ultimately, the adoption of best practices could lead to an enhanced moral climate and improved delivery of ethical care within healthcare settings.

A group of investigators at the Joint Centre for Bioethics (JCB) at the University of Toronto, Canada, recognising the potential value of obtaining further knowledge and understanding about the nature and effectiveness of clinical ethics services utilising this delivery model, designed a study 
Table 1 Description of settings

\begin{tabular}{|c|c|c|c|c|}
\hline Site & Focus of hospital services and activities* & $\begin{array}{l}\text { Location (no of } \\
\text { sites) }\end{array}$ & No of beds & No of intensive care beds \\
\hline 1 & $\begin{array}{l}\text { Geriatric } \\
\text { Jewish faith based }\end{array}$ & 6 & $\begin{array}{l}992 \text { (300 hospital, } 472 \text { long term, } \\
220 \text { supportive housing units) }\end{array}$ & $0 \mathrm{ICU} ; 6$ concentrated care \\
\hline 2 & $\begin{array}{l}\text { Mental health and addiction } \\
\text { Community based health promotion and prevention }\end{array}$ & 4 & 546 & $0 \mathrm{ICU} ; 14$ psychiatric intensive care \\
\hline 3 & Paediatric & 1 & 389 & 36 critical care; 38 neonatal ICU \\
\hline 4 & $\begin{array}{l}\text { Women and infant care, surgery, oncology } \\
\text { Jewish faith based }\end{array}$ & 3 & 462 & $14 \mathrm{ICU} ; 34$ neonatal ICU \\
\hline 5 & $\begin{array}{l}\text { Trauma and inner city care } \\
\text { Catholic faith based }\end{array}$ & 1 & 550 & $60 \mathrm{ICU}$ \\
\hline 6 & $\begin{array}{l}\text { Trauma, women's health, cardiology, oncology, } \\
\text { musculoskeletal care }\end{array}$ & 3 & 980 & $75 \mathrm{ICU}$ \\
\hline 7 & Rehabilitation & 5 & $\begin{array}{l}540 \text { ( } 300 \text { complex continuing care, } \\
240 \text { rehabilitation) }\end{array}$ & $0 \mathrm{ICU}$ \\
\hline 8 & $\begin{array}{l}\text { Oncology, blood disorders, cardiovascular, } \\
\text { transplantation, neurology, community health }\end{array}$ & 3 & 873 & 49 ICU \\
\hline 9 & Community outreach & 1 & 372 & 16 coronary/medical ICU; 10 ICU \\
\hline
\end{tabular}

entitled the Project Examining Effectiveness in Clinical Ethics (PEECE). Using a retrospective case study approach, one of the primary objectives of the first phase of PEECE is to compare and contrast, in a comprehensive fashion, the various clinical ethics services currently being provided at hospitals affiliated to the University of Toronto. Although a lone ethics consultant model was predominant across all the sites, anecdotally it was known that there were significant variations in the structures, activities, and resources of the clinical ethics services. However, the extent and nature of those differences had not been empirically examined. Phase 1 of the study describes, compares, contrasts, and in some instances, quantifies those differences. The project was conceived with a long term vision of developing a set of benchmarking measures for use in clinical ethics. The benchmarking measures would have applicability in local, national, and international settings. In addition to deepening our understanding of the nature and scope of this delivery model of clinical ethics services, findings from phase 1 informed the development of the interview guide used in phase 2 of PEECE. In phase 2, interviews and focus groups are being held with administrators, ethics committee members, healthcare professionals, family members and patients, as well as clinical ethicists to seek an understanding of their definition of clinical ethics, perception of indicators of effectiveness, and previous experiences with the clinical ethics service in their facility. Findings from phase 2 of PEECE will be presented in subsequent publications.

\section{STUDY SITE}

The nine hospital sites that participated in the study included Baycrest Centre for Geriatric Care, Centre for Addiction and Mental Health, the Hospital for Sick Children, Mount Sinai Hospital, Centre for Clinical Ethics-St Michael's Hospital, Sunnybrook and Women's College Health Sciences Centre, Toronto Rehabilitation Institute, University Health Network, and Toronto East General Hospital. All these hospitals are partners of the Joint Centre for Bioethics, University of Toronto, Canada.

\section{METHOD}

From April through December 2003, data to depict the structure, activities, and resources of the clinical ethics services as they existed in June 2003 were collected from the following sources: clinical ethics service reports, committee terms of reference, minutes of committee meetings, and job descriptions. Public documents available through hospital websites and public relations/media departments were also accessed. This descriptive snapshot does not reflect expansions or developments made to enhance ethics programmes at the various sites subsequent to June 2003 (see postscript). Two of the investigators were responsible for collecting and extracting the data, which were entered into grids with column headings that captured the three primary areas of interest: structure, activities, and resources. The grids were developed in collaboration with the PEECE group which is comprised of all of the clinical ethicists working across the nine sites included in the study. Clinical ethicists at each site were asked to review the completed grids for their respective service and to make revisions or additions as needed. From the text that was gathered, content analysis was independently carried out by two of the investigators. Findings were compared and any differences of opinion resolved. Through reading and reflecting upon the data, general themes were identified by two of the investigators. These were presented to the other investigators for discussion and validation.

\section{FINDINGS}

The findings are reported under the following headings: structure, activities, and resources. In the section on structure, a description of the hospital settings in which clinical ethics services are situated is provided. Also included in this section is an overview of each clinical ethics service and its accountability structures. In the activities section, detailed information about programme components and services is outlined. Finally, human, material, and financial resources are identified in the section on resources. Tables with supplementary data accompany the text for each section.

\section{Structure}

All the hospital settings in which the clinical ethics services are located identify three primary areas of focus: patient care, teaching, and research (table 1). Four hospitals serve specific patient populations, including the elderly, persons with mental illness, children, and those with rehabilitation needs. The other five hospitals serve patients with a variety of acute and chronic care needs. Each hospital specialises in a number of areas (for example, transplantation, oncology, trauma). Three hospitals are historically linked with faith based communities and value systems. Six of the nine hospitals are spread geographically across multiple sites, often as a result of organisational mergers. On average, each clinical ethics programme provides services at three 


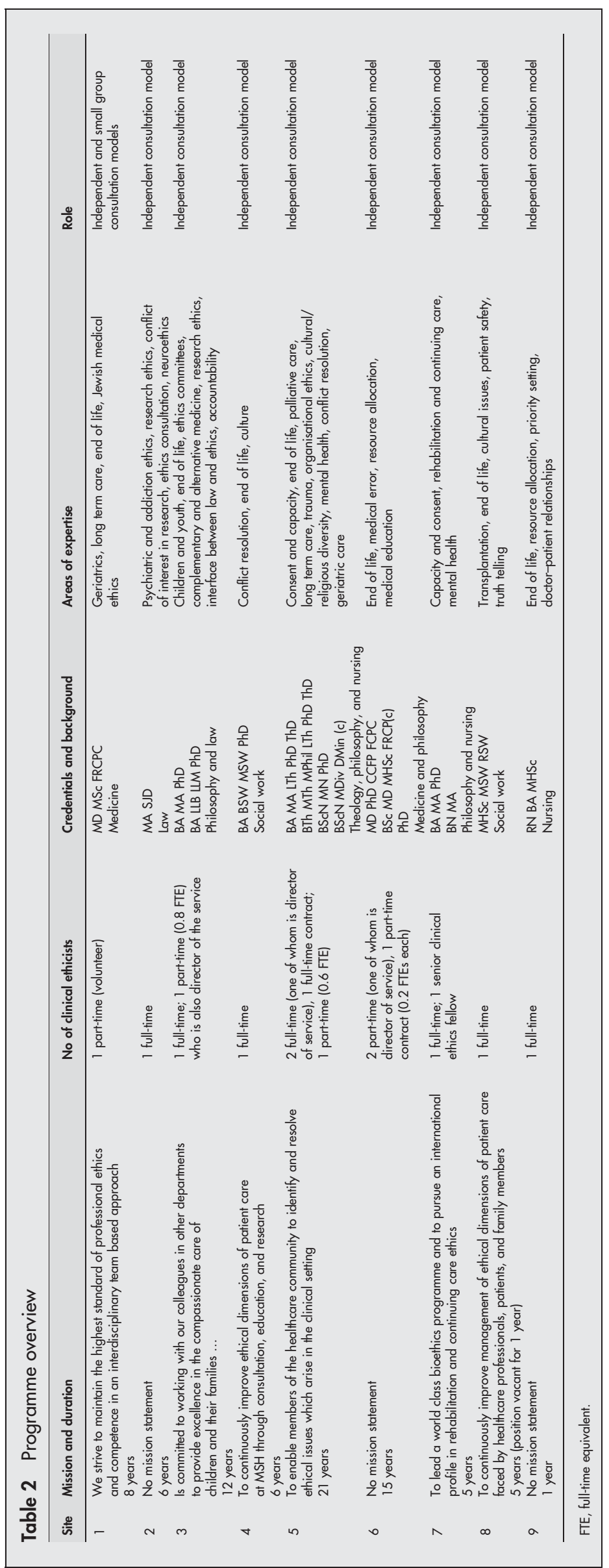

different locations. The size of the facilities ranges from 372 to 992 beds $($ mean $=634)$ including between zero and 75 intensive care beds $($ mean $=39)$.

The clinical ethics services included in this study were established between one and 21 years ago (table 2). Six of the clinical ethics services have existing formal mission statements for their departments. At the time of study, the full-time equivalent (FTE) of clinical ethics positions across clinical ethics services ranged from zero to 3.6 FTEs. (The clinical ethics service with 3.6 FTEs also provides clinical ethics services to three other facilities that were not included in this study. At the site included in the study there was approximately I FTE coverage.) The academic and professional backgrounds of the clinical ethicists include medicine, law, philosophy, social work, theology, and nursing. Most had completed doctoral level education; the minimum preparation was a master's degree in bioethics or philosophy.

The clinical ethicists report a variety of areas of expertise including end of life, culture and religion, mental health, continuing care, consent and capacity, geriatrics, conflict resolution, resource allocation, research ethics, children, neuroethics, ethics committees, complementary and alternative medicine, law and ethics, trauma, medical error, organisational ethics, medical education, transplantation, patient safety, doctor-patient relationships, and truth telling. In all but one of the clinical ethics services, the role of the clinical ethicist is predominantly that of an independent consultant (that is, response to a consult is by an individual clinical ethicist rather than by a multidisciplinary team made up of ethics committee members or the ethics committee as a whole).

Four of the clinical ethics services report directly to the hospital's chief executive officer (table 3). Four report either to a director or vice president within the hospital. One clinical ethics service does not have a formal reporting structure. In the three sites with more than one clinical ethicist, the clinical ethicists report to the director of the ethics centre, and the director of the centre reports to senior management. There is no reference to clinical ethics services in the organisational charts of three hospitals. Six of the nine clinical ethics services prepare written reports ranging in frequency from quarterly to biannually. Three clinical ethics services have completed a strategic planning process and an additional three services are currently conducting or about to engage in a strategic planning process. Formal evaluation processes are also in place in six of the nine sites. These evaluation processes include performance evaluations at five sites, annual review and goal setting at five sites, and evaluative feedback about educational activities at three sites. Performance evaluations generally include self-evaluations and evaluations by the person to whom the clinical ethicist reports. Annual review and goal setting are carried out by the clinical ethicists, in consultation with key stakeholders. Individuals who attend the educational activities provide feedback about the sessions. 
Table 3 Accountability structures

\begin{tabular}{|c|c|c|c|c|c|}
\hline Site & Reporting structure & Location on organisational chart & Written reports & Strategic plan & Evaluation processes \\
\hline 1 & None & Not located & $\begin{array}{l}\text { Periodic verbal } \\
\text { reports }\end{array}$ & None & None \\
\hline 2 & $\begin{array}{l}\text { CEO and executive VP, } \\
\text { policy and planning }\end{array}$ & $\begin{array}{l}\text { Direct line to executive VP, policy } \\
\text { and planning }\end{array}$ & None & Under development & None \\
\hline 3 & Executive VP and COO & Direct line to executive VP and COO & Biannual report & $\begin{array}{l}\text { Completed in conjunction } \\
\text { with hospital strategic } \\
\text { planning process }\end{array}$ & $\begin{array}{l}\text { Performance evaluation, annual } \\
\text { review, goal setting, and education }\end{array}$ \\
\hline 4 & CEO & $\begin{array}{l}\text { Under associate VP of planning and } \\
\text { program development; Ethics Committee } \\
\text { and Research Ethics Board direct line to } \\
\text { Medical Advisory Council Committee }\end{array}$ & Annual summary & None & Performance evaluation \\
\hline 5 & CEO & Direct line to President and CEO & Quarterly reports & None & $\begin{array}{l}\text { Performance evaluation, annual } \\
\text { review, goal setting, and education }\end{array}$ \\
\hline 6 & $\begin{array}{l}\text { Director, quality and risk } \\
\text { management }\end{array}$ & Not located & None & Under development & None \\
\hline 7 & VP, professional practice & $\begin{array}{l}\text { Under VP, professional practice and } \\
\text { CNO }\end{array}$ & Biannual report & Under development & $\begin{array}{l}\text { Annual review, goal setting, and } \\
\text { education }\end{array}$ \\
\hline 8 & Medical director & Not located & Annual report & Yes & $\begin{array}{l}\text { Annual review, goal setting, and } \\
\text { performance evaluation }\end{array}$ \\
\hline 9 & President and CEO & Direct line to President and CEO & None & $\begin{array}{l}\text { Programme proposal } \\
\text { based on needs } \\
\text { assessment and strategic } \\
\text { plan of hospital }\end{array}$ & $\begin{array}{l}\text { Performance evaluation, annual } \\
\text { review, goal setting, and education }\end{array}$ \\
\hline
\end{tabular}

\section{Activities}

Multidisciplinary health ethics committees that focus their attention primarily on advisory, education, and policy issues exist in six of the nine sites and all are chaired or co-chaired by a clinical ethicist (table 4). Only one of these committees engages in the process of ethics consultations and it does so infrequently. Committee members are generally volunteers from a variety of disciplines and often include a community member. Most members have limited ethics knowledge and skills, and thus self-education is one of the committee's primary activities. Every site has a research ethics committee and on all but one a clinical ethicist from the local service sits as a member. The number of other on-site committees with representation from the clinical ethics service varies from zero to 32; the average number of committee memberships (not including health ethics and research ethics committees) per ethicist is just over 10. Policy development and review is a key function for a number of these committees. All clinical ethicists are involved in ethics education both for staff and students; most also participate in community based educational activities. Ethics education includes a wide range of activities from teaching university level courses to graduate and undergraduate healthcare students, to leading small group tutorial sessions, to hospital-wide ethics grand rounds, to unit based in-services, as well as community speaking engagements to local organisations and groups on a wide variety of topics (for example, Advance Care Planning for Senior Citizens Group). The number of ethics consultations ranges from four per year to approximately 250 per year depending on the site. Statistics on the actual number of consults on particular issues are not available. The range of issues for which consultation is sought, however, is reported as far-reaching. Many of the consultations involve ethical issues at the beginning and end of life. Other consultations focus on organisational ethics issues (for example, resource allocation and priority setting), "everyday" ethics issues (for example, privacy, truth telling, confidentiality, sexuality), and relational ethics issues (for example, communication,

Table 4 Programme components and services

\begin{tabular}{|c|c|c|c|c|c|c|}
\hline Site & $\begin{array}{l}\text { Health ethics committee } \\
\text { and ethicist's role }\end{array}$ & $\begin{array}{l}\text { Research ethics } \\
\text { committee and ethicist's } \\
\text { role }\end{array}$ & Other committees & Education & Consults & Scholarly activity \\
\hline 1 & Yes, chair & Yes, not a member & None & $\begin{array}{l}\text { Staff, students, } \\
\text { community }\end{array}$ & Internal (4/year) & $\begin{array}{l}\text { Publications, } \\
\text { presentations }\end{array}$ \\
\hline 2 & $\begin{array}{l}3 \text { committees; chair } 1 \text {, } \\
\text { member } 2\end{array}$ & Yes, member & 8; member/advisor & $\begin{array}{l}\text { Staff, students, } \\
\text { community }\end{array}$ & $\begin{array}{l}\text { Internal and occasional } \\
\text { external ( 132/year) }\end{array}$ & $\begin{array}{l}\text { Research, publications, } \\
\text { presentations }\end{array}$ \\
\hline 3 & No & Yes, member & $\begin{array}{l}32 ; \text { member of } 30 \text {, } \\
\text { chair of } 2\end{array}$ & $\begin{array}{l}\text { Staff, students, } \\
\text { community }\end{array}$ & $\begin{array}{l}\text { Internal and external (number } \\
\text { unknown) }\end{array}$ & $\begin{array}{l}\text { Research, publications, } \\
\text { presentations }\end{array}$ \\
\hline 4 & Yes, co-chair & Yes, member & 1; member & $\begin{array}{l}\text { Staff, students, } \\
\text { community }\end{array}$ & $\begin{array}{l}\text { Internal and external ( } \sim 250 / \\
\text { year) }\end{array}$ & $\begin{array}{l}\text { Publications, } \\
\text { presentations }\end{array}$ \\
\hline 5 & Yes, chair & Yes, member & 12; member & $\begin{array}{l}\text { Staff, students, } \\
\text { community }\end{array}$ & $\begin{array}{l}\text { Internal and external ( } 250 / \\
\text { year) }\end{array}$ & $\begin{array}{l}\text { Research, publications, } \\
\text { presentations }\end{array}$ \\
\hline 6 & Yes, chair & Yes, chair & None & Staff, students & Internal ( 80/year) & $\begin{array}{l}\text { Publications, } \\
\text { presentations }\end{array}$ \\
\hline 7 & Yes, chair & $\begin{array}{l}2 \text { committees, member } \\
\text { of both }\end{array}$ & $\begin{array}{l}\text { 18; member of } 10 \text {, } \\
\text { consultant member of } \\
6 \text {, co-chair of } 1 \text {, chair } \\
\text { of } 1\end{array}$ & Staff, students & $\begin{array}{l}\text { Internal and external }(\sim 130 / \\
\text { year) }\end{array}$ & $\begin{array}{l}\text { Research, publications, } \\
\text { presentations }\end{array}$ \\
\hline 8 & No & 3 committees, member & $\begin{array}{l}\text { 7; member of } 6 \text {, } \\
\text { chair of } 1\end{array}$ & $\begin{array}{l}\text { Staff, students, } \\
\text { community }\end{array}$ & $\begin{array}{l}\text { Internal and external ( } ~ 75 / \\
\text { year) }\end{array}$ & $\begin{array}{l}\text { Research, publications, } \\
\text { presentations }\end{array}$ \\
\hline 9 & $\begin{array}{l}\text { No (planned for September } \\
2004 \text { ) }\end{array}$ & Yes, member & $7 ;$ member of 7 & Staff, students & $\begin{array}{l}\text { Internal and external }(\sim 250 / \\
\text { year) }\end{array}$ & $\begin{array}{l}\text { Publications, } \\
\text { presentations }\end{array}$ \\
\hline
\end{tabular}




\begin{tabular}{|c|c|c|c|c|}
\hline Site & $\begin{array}{l}\text { No of beds per } \\
\text { ethicist }\end{array}$ & $\begin{array}{l}\text { No of ICU* beds } \\
\text { per ethicist }\end{array}$ & $\begin{array}{l}\text { No of outpatient visits } \\
\text { per year per ethicistt }\end{array}$ & $\begin{array}{l}\text { No of emergency room visits } \\
\text { per year per ethicistł }\end{array}$ \\
\hline $1 \S$ & (992) & (6) & $(214000)$ & No ER \\
\hline 2 & 546 & 14 & 519000 & 3600 \\
\hline 3 & 216 & 41 & 177000 & 26900 \\
\hline 4 & 462 & 48 & 635000 & 37000 \\
\hline 5 & 550 & 60 & 503000 & 55600 \\
\hline 6 & 2450 & 188 & 1375000 & 102800 \\
\hline 7 & 540 & No ICU beds & 113000 & No ER \\
\hline 8 & 873 & 49 & 876000 & 73300 \\
\hline 9 & 372 & 26 & 194000 & 61800 \\
\hline Average & 778 & 48 & 511778 & 40111 \\
\hline Average $^{\star *}$ & 751 & 53 & 549000 & 45125 \\
\hline Average†† & 508 & 34 & 431000 & 36886 \\
\hline \multicolumn{5}{|c|}{$\begin{array}{l}\text { *ICU beds include other types of special care beds as described in table } 1 \text {. } \\
\text { †Outpatient visits are rounded to the nearest thousand. Outpatient visits include community and programme visits } \\
\text { but do not include day surgeries. } \\
\text { INumber of emergency room visits is rounded to the nearest hundred. } \\
\text { \$At the time the study was conducted site } 1 \text { did not have a paid ethicist. The numbers reported in parentheses are } \\
\text { the actual number of beds, ICU beds and outpatient visits at the site. } \\
\text { TAverage calculated including all sites. } \\
{ }^{*} \text { Average calculated including all sites, except site } 1 \text { (no paid ethicist). } \\
\text { ††Average calculated including all sites, except site } 1 \text { (no paid ethicist) and site } 6 \text { (outlier). }\end{array}$} \\
\hline
\end{tabular}

teamwork, boundary setting). Most sites conduct both internal and external ethics consultations. The average number of consults per ethicist per year (excluding the site with no paid ethicist which is an outlier with only four consults per year and the site for which these data were not available) is 184. Explicit information about the consultation process itself was not found in the data. However, through the investigators' observations and experiences, it is known that the process may vary from one consult to the next and that different clinical ethicists approach consultations in various ways. Some are directly engaged with the staff, patients, and families involved and take a leadership role in the decision making process; others play a more consultative role and remain largely in the background. The consultation process will be explored in phase 2 of the study. Every clinical ethicist is engaged in scholarly activities of publishing and presenting on ethics related matters and each is a coinvestigator in PEECE. Development of a programme of research is an integral part of the role of clinical ethicists at five of the nine sites.

\section{Resources}

Table 5 presents the characteristics of the potential caseload per ethicist across the various sites. The paid ethicist/ inpatient hospital bed ratio ranges from 1 ethicist for every
216 beds to 1 ethicist for every 2450 beds. The average number of hospital beds per ethicist including all nine sites is approximately 778 . The ethicist/intensive care unit (ICU) or special care bed ratio ranges from 1 ethicist for every 14 beds to 1 ethicist for every 188 beds, with an average of approximately 48 beds. Averages have been calculated in the following two additional ways: (1) excluding site 1 , as there was no paid ethicist at this site at the time of the study; and (2) excluding site 1 (for the reason identified above) and site 6 , as this site appeared to be an outlier on each of the variables examined. Clinical ethicists are also involved with outpatients and each site has a number of outpatient clinics and programmes. The paid ethicist per number of outpatient visits per year ranges from 1 ethicist for every 113000 outpatient visits to 1 ethicist for every 1375000 outpatient visits. The average number of outpatient visits per year per ethicist including all nine sites is 511778 . Ethicists are also called upon to assist with cases in the emergency department. The paid ethicist/emergency room visits per year ratio ranges from 1 per 3600 to 1 per 102800 with the average number of emergency room visits per year per ethicist across all sites being 40111 .

Administrative support differs significantly across sites with four reporting no administrative support for their clinical ethics service (table 6). All sites report having

Table 6 Other resources

\begin{tabular}{|c|c|c|c|c|}
\hline Site & Administrative support & Office space & Library resources & $\begin{array}{l}\text { Computer } \\
\text { resources }\end{array}$ \\
\hline 1 & $\begin{array}{l}\text { Administration secretary provides support } \\
\text { for clinical ethics committee }\end{array}$ & $\begin{array}{l}\text { No dedicated space; uses office for } \\
\text { VP Medicine; adequate }\end{array}$ & On-site; online to University of Toronto & Adequate \\
\hline 2 & $\begin{array}{l}0.5 \text { FTE administration support; additional } \\
\text { support for committee work }\end{array}$ & $\begin{array}{l}\text { Two offices; carrel available for } \\
\text { administration staff; adequate but } \\
\text { not physically proximate }\end{array}$ & On-site; online to University of Toronto & Adequate \\
\hline 3 & 1 full-time administration assistant & Four offices; adequate & $\begin{array}{l}\text { Ethics department library; on-site; } \\
\text { online to University of Toronto }\end{array}$ & Need upgrading \\
\hline 4 & No administration support & Two offices; adequate & On-site; online to University of Toronto & Need upgrading \\
\hline 5 & Part-time secretary & Four offices; adequate & $\begin{array}{l}\text { Ethics department library; } \\
\text { on-site; online to University of Toronto }\end{array}$ & Need upgrading \\
\hline 6 & 0.25 FTE administration assistant & Two offices; adequate & On-site; online to University of Toronto & Adequate \\
\hline 7 & $\begin{array}{l}\text { No administration support; currently under } \\
\text { negotiation }\end{array}$ & Two offices; adequate & On-site; online to University of Toronto & Adequate \\
\hline 8 & No administration support & One office, size good but location isolated & On-site; online to University of Toronto & Adequate \\
\hline 9 & Part-time administration assistant & One office, adequate & On-site & Adequate \\
\hline
\end{tabular}


adequate office space to carry out their activities, but two express concerns that their location is geographically remote from the clinical activities of the hospital. Five of the nine clinical ethics services have offices in more than one location. All have library resources readily available in hospital, as well as online access to the University of Toronto. Two of the services maintain a library with ethics related resources within their departments. All report having adequate computer resources available with three indicating a need to upgrade. Budget information was not available for a number of sites and thus is not included in this report.

\section{DISCUSSION}

The data reported above provide a unique and detailed account of the structure, activities, and resources of clinical ethics services at nine hospital partners of the University of Toronto Joint Centre for Bioethics in Toronto, Canada. Through textual analysis of these data, four general themes emerged-variability, visibility, accountability, and complexity. Each of these themes will be addressed in turn.

\section{Variability}

Unlike many of the clinical ethics services in the USA and other parts of the world which utilise a multidisciplinary ethics committee or subcommittee approach to ethics consultation, ${ }^{12}$ most of the clinical ethicists in this study engaged primarily in the practice of independent consultation. Despite a singular model of service delivery (that is, a lone ethicist model), a high degree of variability was found across the clinical ethics services investigated in this study. Other studies examining clinical ethics services have also reported a great deal of variability from one service to another. ${ }^{13712-14}$ The clinical ethics services in this study demonstrated variability in terms of programme components and distribution of services (including the number of ethics consults); the role and background of the clinical ethicist and the clinical ethics service; the human, material, and financial resources; and reporting structures. The potential case load for ethicists at the various sites based on an analysis of the number of hospital beds, number of ICU beds, number of outpatient visits per year, and annual number of emergency room visits was remarkably different from site to site. The patient populations also differed significantly in terms of age, nature and chronicity of diseases, and acuity of care. A thematic analysis of the mission statements revealed different foci across the clinical ethics services. One of the following three themes was generally predominant in the mission statements: capacity building; recognition as a leader or innovator; or enhanced patient care. The differing levels of resources available to clinical ethics services found in this study reflect similar findings from other studies. ${ }^{7}$ Inclusion of the financial budget allocations for the various clinical ethics programmes would have furthered this comparison of resources. The variability across services may reflect the differing needs of the organisations, some other determinant such as the particular strengths and skills of the clinical ethicist, or it may be spurious. In phase 2 of this study, through interviews and focus groups with stakeholders, the notion of variability and fit with organisational needs will be explored.

\section{Visibility}

It became apparent early in the data collection process that the various clinical ethics services have differing degrees of visibility both internally (within their respective organisations) and externally (to the general public). For example, a search of hospital websites for information about their clinical ethics services revealed little information about either the services provided by clinical ethicists or how and when to access these services. As the internet increasingly becomes a first line source of information for many individuals, the limited exposure on websites may be impacting programme accessibility, particularly for patients and family members.

Although there are conflicting views as to its legitimacy as a marker of effectiveness, the number of consultations has been used as a proxy measure of visibility and accessibility of clinical ethics services. ${ }^{315}$ In the participating sites in this study, the number of consultations varies widely. When the number of consultations was examined in relation to a variety of characteristics of the clinical ethics service and of the clinical ethicists themselves, no relational trends were observed with any of the following: number of ethicists, disciplinary background of ethicists, other activities of the ethicist (committee involvement, research ethics, scholarly activity), number of hospital beds, type of hospital, administrative support, focus identified in mission statement, or years in operation. In the documentation that was reviewed, the challenges to increasing visibility were expressed frequently and strategies to enhance visibility (and accessibility) discussed. A number of sites are in the process of implementing a hub and spoke model as a strategy for increasing visibility, accessibility, and sustainability. ${ }^{16}$ In the hub and spoke model, ethics opinion leaders are identified and integrated into the ethics service. The opinion leaders are predominantly clinicians who are visible and well respected in their clinical areas.

\section{Accountability}

Several authors have argued that clinical ethics services should have sustainable, effective, and clearly identifiable accountability structures in place. ${ }^{32}{ }^{17}$ Most of the clinical ethics services in this study have some sort of formal reporting structure in place, but there are significant differences in the type and frequency of reporting and in the focus of the information reported (for example, performance evaluation, annual review and goal setting, evaluative feedback about educational activities). With the exception of one site, each clinical ethics service has a formal reporting structure, with most reporting to senior management. The reporting structures for three of the clinical ethics services, however, did not appear on the hospital's organisational chart.

Depending on the nature of the reporting relationship, at some sites clinical ethicists have considerable independence and freedom to develop the clinical ethics service as they see fit; at other sites many activities of the clinical ethics service are mandated by senior management. Although it has been suggested in the literature that it is preferable to have clinical ethics services report to senior management ${ }^{3}$ and that an accountability structure is necessary to identify and investigate error in clinical ethics practice, ${ }^{17}$ the impact of differing accountability structures (or none at all) on overall effectiveness of clinical ethics services has not been adequately studied. Evidence of specific procedures for addressing errors in clinical ethics practice was not found in the present study and this represents another area for further exploration. Strategic plans generate the direction for the daily activities of a particular service or agency ${ }^{18}$ and like mission statements provide a guide for measuring accountability. ${ }^{17}$ Given that six sites in this study do not have written strategic plans with clearly identified goals and objectives in place, the effectiveness of these clinical ethics services in meeting organisational goals and objectives is difficult to ascertain. In phase 2, the relation between effectiveness and accountability structures will be explored from the perspectives of a number of key stakeholders. 


\section{Complexity}

One of the most salient findings is the complexity inherent in the provision of clinical ethics services. Within the purview of the clinical ethics services in this study, clinical ethicists have multiple roles and responsibilities (for example, consultant, policy maker, educator, mediator, researcher) requiring a broad and varied skill set and knowledge base. This includes: a working knowledge of ethics theory/literature, the healthcare system, health law, and medical terminology; exemplary communication, mediation, and interpersonal skills; and excellent assessment and analytic skills. ${ }^{190}$ In performing these roles, clinical ethicists are generally required to exhibit traits of "good character" (for example, wisdom, impartiality, fairness, honesty, humility). ${ }^{19}$ Many of the clinical ethicists interface with all levels of the organisation from patients, family, and staff at the bedside to senior management and government officials in the boardroom. As the clients or recipients of clinical ethics services are multiple, clinical ethicists are forced to balance competing individual, institutional, and societal needs and interests.

The fact that many of the clinical ethics programmes provide services to a number of geographically distant sites adds another layer of complexity and engages clinical ethicists in ongoing prioritising of needs across sites. In addition to their clinical responsibilities, many of the clinical ethicists in this study are actively involved in educational and scholarly activities which include staff education, teaching graduate and undergraduate university courses, conducting research, publishing manuscripts in scientific journals, and presenting papers at scholarly conferences.

\section{Limitations of the study}

As data were primarily gathered retrospectively from existing sources, information in all categories was not available across all sites. Additionally, there were differences across sites in terms of the ways in which information was reported making direct comparisons difficult in some categories (for example, variability in reporting periods, programme statistics). Generalisability of the findings to other settings may be limited as the sample was one of convenience and all nine clinical ethics services were situated in large, urban, university-affiliated teaching hospitals in Canada. An additional bias may have been introduced as the clinical ethicist participants are also coinvestigators in the study. We employed two strategies to minimise this potential bias: having a principal investigator who was not a clinical ethicist lead the study; and corroborating data provided by the clinical ethicists with other available sources of documentation whenever possible.

\section{CONCLUSIONS}

This comprehensive description of clinical ethics services across nine sites reflects the concepts of variability, visibility, accountability, and complexity that were evident across and within these clinical ethics services in relation to their structure, activities, and resources. Other clinical ethics services may find the grids developed for this study to be a useful benchmarking tool for collecting and analysing data about their own programmes. Benchmarks including the average number of consults per ethicist per year and the hospital beds/ethicist ratio provide useful programme planning and human resource information for hospital administration and clinical ethics services alike. As the field of clinical ethics continues to grow and gain prominence, the need to attain knowledge about benchmarks, best practices, and measures of effectiveness becomes increasingly significant. An indepth understanding of what clinical ethics services currently look like across a broad variety of hospital settings, as described in this paper, is a necessary first step toward realising this knowledge.

\section{POSTSCRIPT}

Since the collection of these data that describe the status of clinical ethics services in June 2003, clinical ethics services have continued to evolve across the nine participating hospital sites. Among the most significant changes are those that occurred in the area of human resources. In September 2003, Sunnybrook and Women's College Health Sciences Centre hired a full-time clinical ethicist, and in March 2004 they increased the amount of part-time administrative support for clinical ethics services from one to three days per week. In August 2003, the Centre for Clinical Ethics-St Michael's Hospital, supplemented their complement of staff with an additional full-time permanent clinical ethicist position. In July 2003, Baycrest Centre for Geriatric Care hired a part-time clinical ethicist with plans to expand this role to one full-time equivalent divided between two individuals (a 0.8 FTE position and a 0.2 FTE position) in 2004. These significant enhancements in human resources reflect a growing awareness and recognition of the role and need for clinical ethics services by administrators at these member hospitals.

\section{ACKNOWLEDGEMENTS}

The researchers would like to acknowledge the support of Dr P Singer, Director of the Joint Centre for Bioethics, University of Toronto. The authors also wish to acknowledge the contributions and support of the University of Toronto Joint Centre for Bioethics Clinical Ethics Group, as well as the other PEECE Group Investigators (S Berry, K Bowman, G Duval, M Gordon, C Harrison, P Hébert, H Markwell, D Oullet, B Secker, L Wright, and R Zlotnik-Shaul).

\section{Authors' affiliations}

M D Godkin, K Faith, R E G Upshur, S K MacRae, C S Tracy, Joint

Centre for Bioethics, University of Toronto, Toronto, Canada M D Godkin, Centre for Clinical Ethics, a shared service of Providence Healthcare, St Joseph's Health Centre, and St Michael's Hospital, Toronto, Canada

K Faith, Clinical Ethics Service, Sunnybrook and Women's College Health Sciences Centre, Toronto, Canada

R E G Upshur, C S Tracy, Primary Care Research Unit, Sunnybrook and Women's College Health Sciences Centre, Toronto, Canada

Funding for this study was provided by the Joint Centre for Bioethics, University of Toronto.

Research Ethics Board approval to conduct this study was received from all participating sites (Baycrest Centre for Geriatric Care, Centre for Addiction and Mental Health, The Hospital for Sick Children, Mount Sinai Hospital, Centre for Clinical Ethics-St Michael's Hospital, Sunnybrook and Women's College Health Sciences Centre, Toronto Rehabilitation Institute, University Health Network, and Toronto East General Hospital) and the University of Toronto, Toronto, Ontario, Canada.

\section{REFERENCES}

1 Sulmasy DP. On the current state of clinical ethics. Pain Med 2001;2:98.

2 Fletcher J, Siegler $M$. What are the goals of ethics consultation? A consensus statement. J Clin Ethics 1996;7:122-6.

3 Berchelmann K, Blechner G. Searching for effectiveness: the functioning of Connecticut Clinical Ethics Committees. J Clin Ethics 2002;13:131-45.

4 Hoffman DE. Evaluating ethics committees: a view from the outside. Milbank $Q$ 1993;71:677-701.

5 McNeill PM. A critical analysis of Australian clinical ethics committees and the functions they serve. Bioethics 2001;15:443-60.

6 Orr RD, Moon E. Effectiveness of an ethics consultation service. J Fam Pract 1993;36:49-53.

7 Slowther A, Bunch C, Woolnough B, et al. Clinical ethics support services in the UK: an investigation of the current provision of ethics support to health professionals in the UK. J Med Ethics 2001;27:i2-i8.

8 Storch JL, Griener GG. Ethics committees in Canadian hospitals: report of the 1990 pilot study. Healthc Manage Forum 1992;5:19-26. 
9 van der Kloot Meijburg HH, ter Meulen RH. Developing standards for institutional ethics committees: lessons from the Netherlands. J Med Ethics 2001;27:i36-45.

10 White B, Zaner RM, Bliton MJ, et al. An account of the usefulness of a pilot clinical ethics program at a community hospital. Qual Rev Bull 1993;19:17-24.

11 McDaniel C. Enhancing nurses' ethical practice: development of a clinical ethics program. Nurs Clin North Am 1998;33:299-311.

12 Fox MD, McGee G, Caplan A. Paradigms for clinical ethics consultation practice. Camb Q Healthc Ethics 1998;7:308-14.

13 Jurchak $\mathbf{M}$. Clinical ethics consultants: survey and practice. In: Monagle J, Thomasma K, eds. Health care ethics: critical issues for the 21 st century. Gaithersburg, MD: Aspen Publishers, 1998.

14 Kelly S, Marshall PA, Sanders LM, et al. Understanding the practice of ethics consultation: Results of an ethnographic multi-site study. J Clin Ethics 1997:8:136-49.
15 Bacchetta MD, Fins JJ. The economics of clinical ethics programs: a quantitative justification. Camb Q Healthc Ethics 1997;6:451-60.

16 MacRae S, Chidwick P, Berry S, et al. Clinical bioethics integration, sustainability and accountability: the Hub and Spokes Strategy. J Med Ethics (in press).

17 Leeman CP, Fletcher JC, Spencer EM, et al. Quality control for hospitals clinical ethics services: proposed standards. Camb Q Healthc Ethics 1997;6:257-68.

18 Grieshaber L. The healthcare practitioner's handbook of management. Boca Raton, FL: St Lucie Press, 1997.

19 Baylis FE. A profile of the health care ethics consultant. In: Baylis FE, ed. The health care ethics consultant. Totowa, NJ: Humana Press, 1994:25-44.

20 Hoffman D Tarzian A, O'Neill JA. Are ethics committee members competent to consult? J Law Med Ethics 2000;28:30-40.

\section{Clinical Evidence-Call for contributors}

Clinical Evidence is a regularly updated evidence-based journal available worldwide both as a paper version and on the internet. Clinical Evidence needs to recruit a number of new contributors. Contributors are healthcare professionals or epidemiologists with experience in evidence-based medicine and the ability to write in a concise and structured way.

Areas for which we are currently seeking authors:

- Child health: nocturnal enuresis

- Eye disorders: bacterial conjunctivitis

- Male health: prostate cancer (metastatic)

- Women's health: pre-menstrual syndrome; pyelonephritis in non-pregnant women

However, we are always looking for others, so do not let this list discourage you.

Being a contributor involves:

- Selecting from a validated, screened search (performed by in-house Information Specialists) epidemiologically sound studies for inclusion.

- Documenting your decisions about which studies to include on an inclusion and exclusion form, which we keep on file.

- Writing the text to a highly structured template (about 1500-3000 words), using evidence from the final studies chosen, within 8-10 weeks of receiving the literature search.

- Working with Clinical Evidence editors to ensure that the final text meets epidemiological and style standards.

- Updating the text every six months using any new, sound evidence that becomes available. The Clinical Evidence in-house team will conduct the searches for contributors; your task is simply to filter out high quality studies and incorporate them in the existing text.

- To expand the topic to include a new question about once every 12-18 months.

If you would like to become a contributor for Clinical Evidence or require more information about what this involves please send your contact details and a copy of your CV, clearly stating the clinical area you are interested in, to Klara Brunnhuber (kbrunnhuber@ bmigroup.com).

\section{Call for peer reviewers}

Clinical Evidence also needs to recruit a number of new peer reviewers specifically with an interest in the clinical areas stated above, and also others related to general practice. Peer reviewers are healthcare professionals or epidemiologists with experience in evidence-based medicine. As a peer reviewer you would be asked for your views on the clinical relevance, validity, and accessibility of specific topics within the journal, and their usefulness to the intended audience (international generalists and healthcare professionals, possibly with limited statistical knowledge). Topics are usually 1500-3000 words in length and we would ask you to review between 2-5 topics per year. The peer review process takes place throughout the year, and our turnaround time for each review is ideally 10-14 days.

If you are interested in becoming a peer reviewer for Clinical Evidence, please complete the peer review questionnaire at www.clinicalevidence.com or contact Klara Brunnhuber (kbrunnhuber@bmigroup.com). 